\title{
Performance measurement: The next station
}

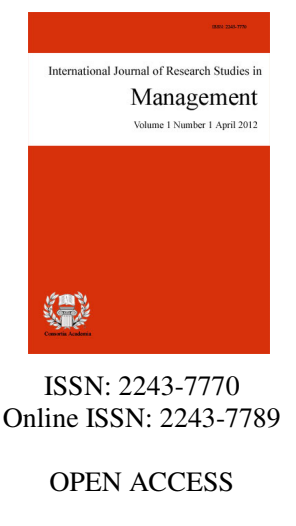

\section{Abstract}

Purpose of this study is to explore how changes in business environment are affecting organizational performance measurement $(\mathrm{PM})$ and furthermore what direction is the PM expected to take in the future. A single instrumental case study was conducted to explore the issue of PM and the changing environment from the perspective of the practitioners. Research was carried out in a large manufacturing organization in Karachi, Pakistan. The key findings from the study include: 1) The concept of a tightly bounded organization as a single, self-contained unit is being replaced by a complex, social structure comprising of multiple interdependent units. 2) Contemporary PM systems use historical data to address the accountability and progress monitoring needs of organizations. 3) The organizations are now realising a need for a PM system capable of predicting the future performance rather than analysing the past achievements, hence it is expected that the future PM system may shape up into a dynamic and flexible planning tool rather than a rigid assessment tool. The study contributes to the extant literature by pointing out the deficiencies in the contemporary PM systems and suggests critical characteristics of the future PM systems which might help organizations in aligning its strategies enabling it to successfully compete in the changed environment.

Keywords: performance management; future of PM; strategy; risk management; PM evolution 


\section{Performance measurement: The next station}

\section{Introduction}

The journey of Performance measurement (PM) has taken it through Fredrick Taylor's efficiency era, Edward Deming's quality control era and Peter Drucker's Customer era, now it is into Kaplan and Norton's multi-perspective era. Balanced Scorecard (BSC) caused a paradigm shift in this journey (see Kaplan \& Norton, 1992 ) as it highlighted importance of non-financial measures. Neely's Performance Prism, (see Neely, Adams, \& Kennerly, 2002) expanded the multiple perspective approach of Balanced Scorecard by including other stakeholders and strategies. The ground-breaking novelty introduced by these frameworks was that it provided an integrated approach to measuring performance. This integration of multiple perspectives in a coherent manner made lot of sense and hence BSC in particular, became quite popular (Greiling, 2010; Hoque, 2014). The world of 1990s, when these frameworks were conceived, was experiencing globalization of businesses. By that time Soviet Union had vanished and with that influence of communism on markets was eroding leaving capitalism to rule as "the" market philosophy. The concept of free markets empowers customers and shareholders, hence the integrated measures that included perspectives of both the customers and the shareholders made perfect sense. Even the nonprofit organizations also started adapting the BSC to measure and report their performance (Greiling, 2010; Niven, 2008). However, the environment in which businesses operate is changing rapidly and some drastic changes are already on the horizon. These environmental changes have necessitated corresponding changes in the business systems. Therefore, many scholars, (see Andersen, Busi, \& Onsoyen, 2014; Melnyk, Bititci, Platts, Tobias, \& Andersen, 2014), have called for a new research agenda in performance measurement in the changed environment. This study is in response to these calls to explore how businesses are responding to the environmental changes in shaping its PM and what will be the new destination of PM in its continuing journey.

The overall purpose of this study was to explore practitioners' views on the need of new developments in PM for it to remain useful and relevant in the changing environment. The study was guided by the following three questions:

RQ 1: What are the major changes currently happening in the environment in which businesses operate today?

RQ 2: What adaptations organizations have already made in their PM systems to cope with the expected changes in the environment?

RQ 3: What changes organizations will need to make in their PM systems to keep the business competitive?

\section{Literature Review}

Today, organizations are acutely aware of the need to perform well to survive and succeed. An organization can reach its goals and deliver on its mission only if it can identify the activities it should complete (Sumardi \& Fernandes, 2018). This, determination of what, when, where, and how about the organizational activities is guided by PM system of the organization.

\subsection{Performance Measurement}

Favoring a traditional view Payer-Langthaler and Hiebl (2013), defined PM as "assessment" of the results from intentional action, whereas Hall (2010), considered PM to be a "system" which translates strategies into results. Others who saw PM as a "tool", for instance, Cruz, Scapens and Major, (2011), argued that PM practices are the actions and tools, which support the assessment of progress of an organization in moving towards its goal and which may become formalized over time. On the other hand, Franco-Santos, Lucianetti, and Bourne (2012), 
emphasized the multi-perspective aspect of PM in their definition: "PM system in an organization exist if financial and nonfinancial performance measures are used to operationalize strategic objectives" (p. 85). The common ground of these various PM definitions, whether explicit or implicit, is the reference to strategy - the action required to achieve the objectives. Thus, it can be safely inferred that in the contemporary literature, role of PM in an organization is expected to be more than simply monitoring the results.

\subsection{Current Issues in Performance Measurement}

To be able to guide an organization to its goals, a PM needs to be flexible, dynamic and future oriented (Laihonen, 2015). However, the practice in reality is different. PM in organizations is static, rigid and continue to rely heavily on traditional accounting system, (Franco-Santos et al., 2012; Neely, 2005; Taticchi, Tonelli, \& Cagnazzo, 2010; Tung, Baird, \& Schoch, 2011). The introduction of multi-dimensional PM systems such as Performance Prism (Neely et al., 2002) or Balanced Scorecard (Kaplan \& Norton, 1992) have certainly enhanced the scope of PM but the underlying design and processes of PM continue to rely on the historical data, this approach, sometimes called "rear-view mirror driving", remains highly prevalent (Tung et al., 2011). In addition to the logical issue of moving forward while looking backwards, and the inherent inertia of PM, literature has identified insufficient planning (Cunha, Vieira, Rego, \& Clegg, 2018), failing to link result with competencies (Poovathingal \& Kumar, 2018), resistance to change (Zacca \& Dayan, 2018), and lack of organizational commitment (Sumardi \& Fernandes, 2018), as the major problems organizations currently face in designing and implementing PM. The failure of PM is quite common and has recently started attracting researchers to look into it in more depth (Norreklit \& Mitchell, 2007). Camp and Braet (2016), observed, a PM may fail at metrics level (incorrect or incomplete set of KPIs), framework level (imprecise scope) and/or management level (lack of commitment or skills).

Sudden news of failure of several big organizations in 1990s was a wakeup call for the regulators which resulted in enactment of new laws (e.g. Sarbanes-Oxley Act of 2002) forcing organizations to more comprehensive and detailed reporting (Ostrower, 2007). Not only the governments, it was also the shareholders, watchdog agencies and the civil society in general which began putting pressure on organizations to be more transparent in their financial reports. This was the start of "accountability movement" (Carman, 2010). Some scholars, (see Ospina, Diaz, \& O'Sullivan, 2002) however, cautioned against the peril of limiting accountability to disclosing financial information and regulation compliance as it fails to inform stakeholders about how well an organization is doing in achieving its mission and goals. Ebrahim and Rangan (2014), echoed similar views and argued to include governance and performance aspects in addition to financial disclosure and compliance in the definition of accountability.

Importance of accountability cannot be overlooked yet there are a growing number of scholars who warn against limiting the PM to externally driven accountability (see Greiling, 2010; LeRoux \& Wright, 2010; Moxham, 2009). These scholars advocate that the central purpose of performance measurement is to generate information for strategic planning, learning and improvement. A similar opinion was expressed by Stufflebeam, Madaus and Kellaghan (2000), who famously said "the purpose of evaluation is to improve, not prove". The idea here is that reporting for the sake of complying with regulations or following a societal trend should not drive the PM, rather it should aim for continuous improvement. Bititci, Garengo, Dorfler, \& Nudurupati, (2012), argued that organizations using PM primarily for learning and improvement faced implementation challenges as it required a cultural change. Furthermore, current PM systems generally are weak in finding a balance between need for accountability and improvement (LeRoux, 2013).

\subsection{Performance Measurement in the Future}

Literature has begun to address the future of PM. The push is coming mostly from the industry though academic circles have also noted the stagnancy in PM research agenda (Melnyk et al., 2014), and the gap between scholars and practitioners (Bourne, 2008). Therefore, next developmental stage of PM is expected to 
focus more on the practical issues currently faced by organizations.

The Information technology revolution (Bititci et al., 2012) and the critical role information assets are playing in globalized economy (Harrison \& Rouse, 2016) along with advances in communication, availability of faster computers and intelligent software is helping to reduce the time lag between data collection and analysis. Aral, Dellarocas and Godes (2013), observed that the use of social media is changing the way organizations operate. Affordable technology is available tempting organizations to acquire it even if it is uncertain how it will help in achieving organizational goals. To guard against such temptations, it is important that technical solutions should be aligned with strategic solutions (Cavaleri \& Shabana, 2018). Focus should be on achieving the mission and adoption of technology should be treated as the means. Taticchi, Garengo, Nudurupati, Tonelli, and Pasqualino, (2014) suggested, organizations need an overall strategy encompassing economic, environmental and social aspects of sustainability for creating competitive advantage. Melnyk et al. (2014) predicted that in future, organizations will be designing their PM systems and strategies together. They further argued, focus of PM system will shift from progress monitoring against set targets to strategizing the actions required to achieve those targets.

Another area where PM is expected to make significant progress is the supply chain management which is becoming increasingly important in determining success of an organization (Narasimhan, 2018). Therefore, measuring how efficient and effective these processes are should be a part of an organizational PM system. Specific common metrices will need to be developed for this purpose and a strong collaboration and mutual trust will be required between partners. The existing knowledge in the area of performance measurement needs to be extended to cover the needs of a supply chain, where collaboration and information sharing practices integrate the participating companies into a single and integrative unit. There are several challenges in developing a PMS for supply chain including data management, process management and collaboration (Papakiriakopoulos \& Pramatari, 2010). Interestingly, partners tend to agree more readily on non-financial measures than financial measures because the resources are common and the cost centers are different for the partners. Quality of information is another major obstacle in the context of planning supply chain activities and therefore creates reliability issues in performance assessment of the supply chain (Simchi, Kaminsky, \& Simchi, 2008).

Neely (2005) reminded, a PM system is needed not only for internal management purposes but external agencies are also demanding more information about performance. Clearly, accountability and desire to be seen as transparent will continue to influence the PM in future as well as it is doing now. However, Nicholson, Pugliese and Bezemer (2017, p. 239) pointed out, accountability is a socially constructed phenomenon thus, understanding the social processes of accountability is critical for developing future models of PM. The future designers of PM frameworks should consider this social aspect of accountability and build in room for subjective measures in addition to the objective measures.

The advent of twenty-first century is characterized by generation of enormous volumes of data which is accessible to organizations is making the organizations nervous that they may be missing out on some critical information or a unique opportunity. Thus, big data may have a future role in PM though it is not apparent at this stage how this can be usefully employed by organizations for performance enhancement (Nudurupati, Tebboune, \& Hardman, 2016). Obviously, organizations will need to develop the structures and skills to manage big data and see if the related costs can be justified by the expected gains.

Melnyk et al. (2014) saw strong evidence of structural changes in the environment and organizations adjusting their strategies. A performance measurement system which takes account of the changing business environment is a clear requirement of organizations but current PM systems lack the ability to incorporate the context or the business environment in its processes (Sarmad, 2018). Since the need has already been voiced, it's a matter of time that a PM system with such capabilities will surface soon (Fuehles-Ubach, 2018). Concluding a recent study on evolution of PM, Sarmad, (2018, p. 249) posited "the direction in which PM seems to be moving is that it will be able to tell the stakeholders not only where the organization stands currently but also where it is 
headed".

On the basis of literature review and author's own experience a conceptual framework is designed to explore the PM issue as shown in Figure 1. Societal environment and industrial environment impact the PM design and practices in an organization. The societal factors include change in accountability expectation in societies, advancement in communication and other technologies, and increased pressure to remain sustainable. Industrial environment changes include access to information and big data, increased dependence on supply chain partners and need for continuous improvement.

\section{Methodology}

Single instrumental case study method was followed in this research. Instrumental case study is a term coined by Stake, (2000) who defined it as a method of research in which the researcher examines a particular case only to provide insight into an issue and the case organization serves only to facilitate the in-depth understanding of the issue. Proponents of case study method stress the value in focusing on one case to understand the complex dynamics of the problem (Hyett, Kenny, \& Dickson-Swift, 2014). Merriam, (1998) presented the following argument in favor of case study:

"A case study design is employed to gain an in depth understanding of the situation and meaning for those involved. The interest is in [.....] discovery rather than confirmation. Insights gleaned from case studies can directly influence policy, practice, and future research.” (p. 19)

For this study a private limited, manufacturing company based in Karachi, Pakistan was selected. The company is the largest in its sector and is listed on Karachi stock exchange. The company was established about twenty years ago. In qualitative research, selection of organization/s and participants is usually done through purposive sampling which is based on pre-determined criteria and not on statistical probability theories (Curtis, Gesler, Smith, \& Washburn, 2000). Purposive sampling is "the strategic selection of where, when, and from whom data will be collected based on the objectives of the study" (Palys, 2008, p. 697). The main principle in selecting organization/s or individuals in a qualitative study, Maxwell (2013) stated, is to identify organizations and individuals that best exhibit the phenomenon which is being studied. Purposive sampling has the potential to produce most information about the phenomenon under investigation and is thus typical of case study method (Bloomberg \& Volpe, 2012). In this method, the researcher selects the sample as it helps in "understanding of the research problem and the central phenomenon in the study" (Creswell, 2007, p.125). The criteria used for selecting organization was that it should be large, private company, operating for at least ten years, profitable, using a formal PM system, and accessible. Eight short-listed companies fulfilling the criteria were contacted and finally one that agreed to participate in this research was selected.

Interview is arguably the most widely used method in qualitative research (Bryman \& Bell, 2015). Semi-structured interview offers the potential to capture rich and thick descriptions of the interviewee's perspective (Denzin \& Lincoln, 2013). In this study, interview protocol adapted from Bloomberg and Volpe (2012) was followed. Informed consent from participants was obtained and confidentiality was ensured. The interview questions (see Appendix A) were exploratory in nature, aligned with the key research queries, which were asked of all participants.

A total of seven managers from diverse professional backgrounds were interviewed. Three of the managers interviewed were female and four were male. List of interviewees is provided as Appendix B. For the purpose of this study a manager is defined as an employee who is responsible for certain groups of tasks and report directly to the chief executive or the Board of Directors. Each interview lasted about one hour. Interviews were recorded and transcribed with the consent of the participants. The primary data obtained from interviews was supplemented by collecting other relevant documents such as meeting notes, presentation slides, HR manual, Vision 2030 and literature to triangulate the findings (Yin, 2014). 
As advised by Bryman and Bell, respondent validation and triangulation were used to enhance the research method's credibility. Respondent validation is a process in which the investigator provides the study findings to the participants. In this study, the participants were involved at two stages to corroborate authors understanding. First, the interview transcripts were sent to the interviewees to provide them the opportunity to disagree with or clarify any point as per their understanding. Second, the draft findings were shared with the participants to ensure that the conclusions drawn were based on our common understanding. To further enhance method credibility, triangulation technique was used by using multiple sources of data (Bryman \& Bell) to build explanation. These sources included interviews, observations, documents and field notes. To establish confirmability, detailed records of the process were maintained to build an audit trail (Creswell, 2016). Generalizability is not the intended aim of this research but as Patton, (2015) advocated context-bound extrapolation can be useful in similar (and not necessarily identical) environment. This study may also serve as an initial work paving the way for future studies to build on this research.

For data analysis, procedure suggested by Creswell (2016), was followed. Interview transcriptions were read several times and codes were assigned which were later grouped into patterned themes. The discovered themes are presented in the findings section. For explanation of the themes support was sought from the extant literature. The discrepancies are highlighted and an alternate explanation is offered in the final section.

\section{Findings and Discussion}

The case company is a private limited, manufacturing company based in Karachi, Pakistan. The company is the largest in its sector and is listed on Karachi stock exchange. The company was established about twenty years ago and has grown three-fold since its inception in terms of production capacity. The company has been in profit for the past sixteen years and has been paying dividend to its shareholders regularly. The company implemented an adapted version of Balanced Scorecard six years ago and still uses it with minor modifications.

Analysis of interviews, documents and notes revealed five expected and two un-expected themes as summarized in Table 1. These themes are the significant changes in societal and industrial environments that are recent and have or may influence PM as perceived by the participants. The themes along with the impact they have already made on the PMS and the possible change it may have in future are discussed in the following sections.

\subsection{Accountability}

All seven participants talked about the increasing demand of shareholders, regulators, suppliers, customers and the civil society for more transparency and higher level of accountability. The CFO said:

"I remember when the company was newly established, for several years we would send our annual report to the shareholders and they were satisfied. We filed our tax-returns and the government was satisfied. Suppliers and customers minded their own business and showed no interest in our internal processes or anything. But now, Oh My God, we are expected to be accountable to anyone who walks through".

The Manager IT echoed similar views, she said:

"We have created a separate section which deals with media.... and others to answer their queries. The section has a person each from marketing, finance and IT".

All participants were contented with the way their company has responded to the accountability demand. However, two participants suggested the company will need more decentralization in its decision-making process to maintain transparency. 


\subsection{Sustainability}

Six participants considered predicting sustainability as the primary purpose of PM. They saw increased competition, cost cutting, and availability of cheaper alternatives as a possible threat to organization's long-term sustainability. However, they expressed satisfaction with the way the company is dealing with the increased competition and other threats to sustainability. Though a majority of them also noted that the current measures (quantitative metrics) will not be sufficient in the future and will need to incorporate market intelligence (Director HR), competitors plans (Manager Marketing) and all significant risk factors (GM Production).

\subsection{Dynamic Environment}

All participants identified the rapid and sometimes unanticipated changes in business environment as a major element though they used different words e.g. the Manager Quality Control said "the only constant today is the change itself. It's a moving train. The scene changes every day." The CFO said "it is the speed of change that has changed". Participants were aware of the changes in technology, legal requirements, awareness level in society, customer needs, shareholders expectations, outsourcing possibilities and other factors. The point most of them were driving at was that change is everywhere and this situation of flux has become a norm. Only one participant thought that the company is well equipped to respond to these changes but all others were quite skeptical. For instance, GM Production commented "We know that the environment is dynamic but we assume it to be static when we are making a strategy. It may not be a completely valid assumption but our systems require a constant or at least a stable input". Similarly, GM Corporate Affairs mentioned that there are hundreds of variables that may affect the organization but they do not have capability to capture and process all kinds of data. She further said it would be impractical even foolish to try to monitor every possible variable, and somewhat sheepishly she admitted, that in fact the company doesn't know what to measure. The CFO and Director HR both agreed that the company needs a system which is flexible enough to incorporate new situations (variables) and responsive in a way that it can be calibrated quickly to get results.

\subsection{Frequency}

Five participants mentioned frequency of the PM. Interestingly, two participants - Director HR and CFO remarked about it quite positively. The Director HR said "PM is taken very seriously here. We do it religiously twice a year. You should see our reports - it is not just numbers, we have all kinds of charts and graphs also. It is quite colorful". But GM production, Manager IT and Manager Marketing came out quite strongly in pointing out what they saw as major weakness in the PM system. The Manager Marketing said, "Each department has well defined target and measures our progress regularly, but it is always looking backwards, what I'll call rear view mirror method". GM Production echoed similar view, he mentioned target setting and progress monitoring as separate exercises. He said, "I am required to report on the targets which I do but I am hardly involved in setting those targets. It is the marketing department which dictates here".

Manager IT saw a need for the company to moving on to a system capable of providing online and real time data for decision-making. The CFO acknowledged the need but pointed out that it will be quite costly and wasn't sure if the Board will be willing to invest in this yet.

\subsection{Big Data Concept}

Four participants considered it important and significant for decision making. But all of the four agreed that at present the company didn't have the expertise to manage big data concept. The Manager IT and the CFO admitted that the company has never seriously discussed the possibility of making use of big data concept. They thought the company should wait till the time that future technology simplifies the process and its useful is clearly demonstrated. Manager Marketing believed it more pragmatic to "purchase the information from specialising companies". 


\subsection{Risk}

Four participants pointed out that PM and risk assessment have similar goals hence should be combined. This is an unexpected finding as it is only recently that scholars have started talking about it. The fact that four out of seven participants talked about integrating risk and PM, without a direct question on it, indicates a gap between practitioners and scholars. Manager Quality Control commented:

"You have not asked about risk assessment but I think it should be an integral part of the PM system. In fact, the PM should focus on the future and not just look at the past and make decisions. And when you look at the future, obviously you have to talk about risk. I have heard our Finance department maintains a risk register which I assume includes financial items but what about other risks such as change in demand, technology, competition and so on. Who looks at that? I am not too sure. And before you ask me why I haven't done anything about it, let me admit, I don't know if it is even doable".

Manager Marketing expressed similar view and said that all departments are cognizant of the risks in their own field and are expected to build in mitigating measures in their annual plans but it is not factored in the PM system. This is an important finding. It establishes that the practitioners are aware of the need and understand the solution but due to lack of adequate tools they have not been able to move forward with this idea.

\subsection{Partnership Model}

This is another interesting and somewhat unexpected finding. Four participants directly mentioned "partnerships" as the new business model. In addition, two other participants pointed out the need of sharing data with stakeholders/partners. All of these six participants mentioned the point repeatedly while answering to questions in section 3 which deals with the central question: "what changes organizations will need to make in their PM systems to keep the business competitive"? Majority of the participants envisioned a future where their organization will be much more dependent on third parties for its success. The words, "suppliers, dealers, retailers, watch dog agencies, bloggers, society" were frequently used as who could influence the PM in future.

GM Production said: "we are so heavily dependent on our suppliers - and they on us, that we should start including them in our "internal meetings". The Marketing Manager was quite clear in suggesting that "we must share our data honestly with our dealers and retailers if we expect a similar information from them". Other participants also echoed parallel comments emphasising the need to understand the concerns of stakeholders and get benefit from their experiences. Director HR stated "we have been successful in creating a very cordial, trusting and motivating environment for our internal partners (employees), now it's time to extend it to our external partners". Clearly, the majority of the participants which form the crux of the management of this company see the operating model of the company as changing from a cohesive, self-contained unit to a multi-unit system having common interest and goals. For this system to work, the participants were aware, trust will be needed. As the Director HR pointedly said, "mutual trust and mutual benefit comes together".

Partnerships, like any other relationship, work if it offers a win-win situation for all parties. The duration and strength of this relationship depends on the level of trust partners have on each other. If a partner perceives unfairness in the distribution of gains and/or responsibilities, the partnership cannot last long. Hence, in addition to the formal provisions and controls, transparency and fairness can go a long way to help all partners grow and achieve their mission. 
Table 1

Impact of Factors on PMS

\begin{tabular}{|c|c|c|}
\hline Themes & Current Status of PMS & Future Characteristics of PMS \\
\hline Accountability & Transparent, objective & Decentralized \\
\hline Sustainability & Measured through quantitative metrics & $\begin{array}{l}\text { Measured through quantitative \& qualitative } \\
\text { metrices }\end{array}$ \\
\hline Dynamic & Rigid, trigger points are unclear & Flexible, responsive \\
\hline Environment & & \\
\hline Frequency & Regular, rear mirror view & Continuous, real-time \\
\hline Big Data Concept & Limited use & Technology enabled \\
\hline Risk & Risk assessment is separately done & Integrated with risk monitoring system \\
\hline Partnership Model & $\begin{array}{l}\text { No direct input or influence of } \\
\text { stakeholders }\end{array}$ & Design input \& monitoring by stakeholders \\
\hline
\end{tabular}

It is interesting to note that organizational culture, a recurring theme in similar studies (see Bititci et al, 2012; Nudurupati et al., 2016), was not considered significant by any participant in this study. One possible explanation is that organizational culture in this particular organization is a non-issue as claimed by the HR Director. Thus, the participants take it as granted, stable and do not expect it to change in the near future. On the other hand, this may also be a result of the questions asked of the interviewees which did not specifically mentioned organizational culture, leadership style, or values which could have prompted the participants to reflect on it.

\section{Conclusion}

The study resulted in some interesting findings. First, the environment in which businesses operate today is changing rapidly and at many fronts. It is not only the technology that is changing but also the behavior of people. The concept of a tightly bounded organization as a physical structure and a single unit is being replaced by a complex, social structure comprising of multiple interdependent units. This finding is in line with Nudurupati et al. (2016), who found that organizations need to "incorporate evaluation of their performance over wider networks involving various stakeholders' (p. 232). Second, current PM systems were designed for accountability and monitoring progress against predetermined targets and to highlight variances. These purposes are being adequately served. However, better technology and some fine tuning such as including qualitative metrices can improve the efficiency of PM. This finding supports other studies who have concluded that contemporary PM delivers to a significant degree on accountability and monitoring fronts (Franco-Santos et al., 2012; Greiling, 2010). Third, purpose of PM is now supposed to be much more than monitoring. It is expected to be a predictor, a planning tool, flexible and dynamic. Although scholars have mentioned the need for a flexible and dynamic PM (Melnyk et al., 2014; Nudurupati et al., 2016), this study expands this view and suggests a need to reconceptualize the PM as a planning tool rather than an assessment tool. This is a paradigm shift in the world of PM systems. Contemporary PM systems are not adequately equipped or designed to serve this changed scenario. The businesses are quite clear what they want out of their PM systems in the future, they might need help in designing such systems.

\subsection{Implications and limitations of the research}

The study contributes to the extant literature on PM specifically highlighting the paradigm shift in the purpose of PM which is happening now. The research pointed out the deficiencies in the contemporary PM systems and suggests critical characteristics of the future PM systems. The research findings can help the organizations in reviewing and updating their performance measurement system designs and get much more out of it than what they are getting currently. The study can also trigger more research and discussion among practitioners and scholars on how the contemporary PM paradigm needs to be changed to make it more useful. However, it must be noted that this study was exploratory in nature and was conducted in a single organization. Another limitation was that all participants were similar (manager) level employees. It is possible that CEO, 
Hasan, S. S.

Board Directors or junior employees may have different perspectives. The study identified key issues in the functioning of performance management, which could help managers in developing measures to keep PM system relevant and useful in the future.

\subsection{Recommendations}

As the research subject is quite new, a number of recommendations for future research can be derived from this study. For instance, it will be interesting to include other stakeholders in addition to the employees in a future research to get their perspective on PM of an organization they have a stake in. Integration of risk assessment and PM is another area where scant research is done and so understanding of how it will influence the practice is unclear. Moreover, how this dual role of a planning tool as well as a monitoring tool that PM is expected to play will influence financial reporting is another avenue for future researchers. Finally, this paper supports the view expressed by Melnyk et al. (2014); Nudurupati et al. (2016), and others that more studies are needed to research PM issues in different contexts.

\section{References}

Andersen, B., Busi, M., \& Onsoyen, L.E. (2014). Performance management practice and discipline: moving forward or standing still? International Journal of Business Performance Management 15(2), 117-126. https://doi.org/10.1504/IJBPM.2014.060149

Aral, S., Dellarocas, C., \& Godes, D. (2013). Introduction to the special issue - Social media and business transformation: A framework for research. Information Systems Research, 24(1), 3-13. https://doi.org/10.1287/isre.1120.0470

Bititci, U., Garengo, P., Dorfler, V., \& Nudurupati, S. (2012). Performance measurement: Challenges for tomorrow. International Journal of Management Review, 14(3), 305-327. https://doi.org/10.1111/j.1468-2370.2011.00318.x

Bloomberg, L. D., \& Volpe, M. (2012). Completing your qualitative dissertation: A roadmap from beginning to end $\left(2^{\text {nd }}\right.$ ed.). Thousand Oaks, CA: Sage.

Bourne, M. (2008). Performance measurement: learning from the past and projecting the future. Measuring Business Excellence, 12(4), 67-72. https://doi.org/10.1108/13683040810919971

Bryman, A., \& Bell, E. (2015). Business research methods. Oxford University Press.

Camp, J.V., \& Braet, J. (2016). Taxonomizing performance measurement systems' failures. International Journal of Productivity and Performance Management, 65(5), 672-693. https://doi.org/10.1108/IJPPM-03-2015-0054

Carman, G. (2010). The accountability movement: What's wrong with this theory of change? Nonprofit and Voluntary Sector Quarterly, 39(2), 256-274. https://doi.org/10.1177/0899764008330622

Cavaleri, S., \& Shabana, K. (2018). Rethinking sustainable strategies. Journal of Strategy and Management. https://doi.org/10.1108/JSMA-08-2016-0050

Creswell, J. W. (2007). Qualitative inquiry and research design: Choosing among five traditions ( $2^{\text {nd }}$ ed.). Thousand Oaks, CA: Sage.

Creswell, J.W. (2016). 30 essential skills for the qualitative researcher. Thousand Oaks, CA: Sage.

Cruz, I., Scapens, R. W., \& Major, M. (2011). The localisation of a global management control system. Accounting, Organizations and Society, 36(7), 412-427. https://doi.org/10.1016/j.aos.2011.08.001

Cunha, M.P., Vieira, D.V., Rego, A., \& Clegg, S. (2018). Why does performance management not perform? International Journal of Productivity and Performance Management, 67(4), 673-692. https://doi.org/10.1108/IJPPM-11-2016-0243

Curtis, S., Gesler, W., Smith, G., \& Washburn, S. (2000). Approached to sampling and case selection in qualitative research: examples in the geography of health. Social Science \& Medicine, 50, 1001-1014. https://doi.org/10.1016/S0277-9536(99)00350-0

Denzin, N. K., \& Lincoln, Y. S. (2013). Strategies of qualitative inquiry. SAGE Publications. 
Performance measurement: The next station

Ebrahim, A., \& Rangan, V. K. (2014). What impact? A framework for measuring the scale and scope of social performance. California Management Review, 56 (3), 118-141. https://doi.org/10.1525/cmr.2014.56.3.118

Franco-Santos, M., Lucianetti, L., \& Bourne, M. (2012). Contemporary performance measurement systems: A review of their consequences and a framework for research. Management Accounting Research, 23(1), 79-119. https://doi.org/10.1016/j.mar.2012.04.001

Fuehles-Ubach, S. (2018). What is your contribution to the funder's strategy? Library Management, 39(3/4), 146-153, https://doi.org/10.1108/LM-10-2017-0112

Greiling, D. (2010). Balanced scorecard implementation in German non-profit organisations. International Journal of Productivity and Performance Management, 59(6), 534-554. https://doi.org/10.1108/17410401011063939

Hoque, Z. (2014). 20 years of studies on the balanced scorecard: trends, accomplishments, gaps and opportunities for future research. British Accounting Review, 46(1), 33-59. https://doi.org/10.1016/j.bar.2013.10.003

Hall, P. D. (2010). Historical perspectives on nonprofit organizations in the United States. In R. Herman, R. and Renz, D. (Eds.), The Jossey-Bass Handbook of Nonprofit Leadership and Management (pp. 3-41). San Francisco, CA: Jossey-Bass.

Harrison, J., \& Rouse, P. (2016). Editorial: Performance measurement beyond best practice: Tools for tomorrow's organization. Pacific Accounting Review, 28(4), 362-363.

https://doi.org/10.1108/PAR-09-2016-0082

Hyett, N., Kenny, A., \& Dickson-Swift, V. (2014). Methodology or method? A critical review of qualitative case study reports. International Journal of Qualitative Studies on Health and Well-being. https://doi.org/10.3402/qhw.v9.23606

Kaplan, R., \& Norton, D. (1992). The balanced scorecard: measure that drive performance. Harvard Business Review, 70 (1), 71-79.

Laihonen, H. (2015). Performance improvement in twenty-first century organizations: models, tools, techniques. Measuring Business Excellence, 19(3). https://doi.org/10.1108/MBE-06-2015-0032

LeRoux, K. (2013). Managing stakeholder demands: Balancing responsiveness to clients and funding agents in nonprofit social service organizations. In Osborne, S. (Ed.), Voluntary and non-profit management (pp. 213-238). London: Sage Publications. https://doi.org/10.1177/0899764009359942

LeRoux, K., \& Wright, N. (2010). Does performance measurement improve strategic decision making? Findings from a national survey of nonprofit social service agencies. Nonprofit and Voluntary Sector Quarterly, 39(4), 571-587.

Maxwell, J. A. (2013). Qualitative research design: An interactive approach (3 ${ }^{\text {rd }}$ ed.). Thousand Oaks, CA: Sage.

Melnyk, S., Bititci, U., Platts, K., Tobias, J., \& Andersen, B. (2014). Is performance measurement and management fit for the future? Management Accounting Research, 25, 173-186. https://doi.org/10.1016/j.mar.2013.07.007

Merriam, S. B. (1998). Qualitative research and case study applications in education. San Francisco, CA: Jossey Bass.

Moxham, C. (2009). Performance measurement: Examining the applicability of the existing body of knowledge to nonprofit organisations. International Journal of Operations and Production Management, 29(7), 740-763. https://doi.org/10.1108/01443570910971405

Narasimhan, R. (2018). The fallacy of impact without relevance - reclaiming relevance and rigor. European Business Review, 30(2), 157-168. https://doi.org/10.1108/EBR-01-2017-0005

Neely, A. (2005). The evolution of performance measurement research: developments in the last decade and a research agenda for the next. International Journal of Operations \& Production Management, 25(12), 1264-1277. https://doi.org/10.1108/01443570510633648

Neely, A., Adams, C., \& Kennerley, M. (2002). The performance prism: The scorecard for measuring and managing business success. London, UK: Pearson Education Ltd.

Nicholson, G., Pugliese, A., \& Bezemer, P. (2017). Habitual accountability routines in the boardroom: how 
boards balance control and collaboration. Accounting, Auditing \& Accountability Journal, 30(2), 222-246.

Niven, P. (2008). Balanced scorecard: Step-by-step for government and nonprofit agencies. New Jersey: Wiley.

Norreklit, H., \& Mitchell, F. (2007). The balanced scorecard. In Hopper, T., Northcott, D., \& Scapens, R. (Eds.), Issues in management accounting (3rd ed., pp. 175-198). FT Prentice Hall. Pearson education Limited.

Nudurupati, S. S., Tebboune, S., \& Hardman, J. (2016). Contemporary performance measurement and management (PMM) in digital economies. Production Planning \& Control, 27(3), 226-235. https://doi.org/10.1080/09537287.2015.1092611

Ospina, S., Diaz, W., \& O’Sullivan, J.F. (2013). Negotiating accountability: Managerial lessons from identify-based nonprofit organizations. Nonprofit and Voluntary Sector Quarterly, 31(1), 5-31. https://doi.org/10.1177/0899764002311001

Ostrower, F. (2007). Nonprofit governance in the United States, findings on performance and accountability from the first national representative study. The Urban Institute Center on Nonprofits and Philanthropy. Retrieved from http://www.urban.org/UploadedPDF/411479

Papakiriakopoulos, D., \& Pramatari, K. (2010). Collaborative performance measurement in supply chain. Industrial Management \& Data Systems, 110(9), 1297-1318. https://doi.org/10.1108/02635571011087400

Patton, M. Q. (2015). Qualitative evaluation and research methods $\left(4^{\text {th }}\right.$ ed.). Thousand Oaks, CA: Sage.

Payer-Langthaler, S., \& Hiebl, W. (2013). Towards a definition of performance for religious organizations and beyond: A case of Benedictine abbeys. Qualitative Research in Accounting \& Management, 10(3/4), 213-233. https://doi.org/10.1108/QRAM-08-2012-0033

Poovathingal, J. S., \& Kumar, D. V. (2018). Quantifying the contribution of competencies toward performance. International Journal of Productivity and Performance Management, 67(4), 693-716. https://doi.org/10.1108/IJPPM-12-2016-0267

Sarmad, S. H. (2018). Performance Measurement: How far it has traveled and where is it headed. International Journal of Economics, Commerce and Management, 6(4), 238-251.

Simchi-Levi, D., Kaminsky, P., \& Simchi-Levi, E. (2008). Designing and Managing the Supply Chain: Concepts, Strategies, and Case Studies. McGraw-Hill, Boston, MA.

Stake, R. E. (2000). Case Studies. In N.K. Denzin \& Y.S. Lincoln (2nd ed.), Handbook of qualitative research (pp. 435-454). Thousand Oaks, CA: Sage.

Stufflebeam, D., Madaus, G., \& Kellaghan, T. (Eds.). (2000). Evaluation models: Viewpoints on educational and human services evaluation (Vol. 49). Netherlands: Springer. https://doi.org/10.1007/0-306-47559-6

Sumardi, \& Fernandes, A. R. (2018). The mediating effect of service quality and organizational commitment on the effect of management process alignment on higher education performance in Makassar, Indonesia. Journal of Organizational Change Management, 31(2), 410-425. https://doi.org/10.1108/JOCM-11-2016-0247

Taticchi, P., Tonelli, F., \& Cagnazzo, L. (2010). Performance measurement and management: A literature review and a research agenda. Measuring Business Excellence, 14(1), 4-18. https://doi.org/10.1108/13683041011027418

Taticchi, P., Garengo, P., Nudurupati, S. S., Tonelli, F., \& Pasqualino, R. (2014). A review of decision-support tools and performance measurement for sustainable supply chain management. International Journal of Production Research, 53(21), 6473-6494. https://doi.org/10.1080/00207543.2014.939239

Tung, A., Baird, K., \& Schoch, H.P. (2011). Factors influencing the effectiveness of performance measurement systems. International Journal of Operations and Production Management, 31(1), 1287-1310. https://doi.org/10.1108/01443571111187457

Yin, R. K. (2014). Case study research: Design and methods (5 ${ }^{\text {th }}$ ed.). Thousand Oaks, CA: Sage.

Zacca, R., \& Dayan, M. (2018). Linking managerial competence to small enterprise performance within the dynamic capability logic. Journal of Small Business and Enterprise Development, 25(2), 256-276. https://doi.org/10.1108/JSBED-02-2017-0042 


\section{Appendices}

\section{Interview Questions}

RQ1: What are the major changes currently happening in the environment in which businesses operate today?

i. How internet proliferation has impacted your business in the last three to five years?

ii. What influence social media has on your business? And why is that so?

iii. How can the emerging technologies e.g. 3D printing, artificial intelligence, robotics, virtual reality and others has affected / can affect your organization?

iv. Do you see outsourcing as a threat or an advantage? And why?

v. How can climate change agenda affect business of your organization?

vi. How important is Supply Chain management to the business of your organization?

vii. How data management procedures have changed in your organization in the last three years?

viii. Identify three top business environment changes happened in the last three to five years that are affecting your organization?

RQ 2: What adaptations organizations have already made in their PM systems to cope with the expected changes in the environment?

i. What is the purpose of PMS in your organization?

ii. What are the characteristics of your organization's PMS?

iii. How often PMS is changed in your organization?

iv. When was the last time PMS was changed in your organization?

v. What are the recent changes made in PMS in your organization?

vi. What is the process for making a change in the PMS in your organization?

RQ 3: What changes organizations will need to make in their PM systems to keep the business competitive?

i. What do you consider will be the purpose of PM after five years?

ii. In what ways the changes in business environment impact PM?

iii. What should be the basis of making a change in PMS?

iv. Who should decide if PMS needs to be changed?

v. Who should be involved in designing the PMS? 
Hasan, S. S.

List of Interviewees

\begin{tabular}{lcc}
\hline \multicolumn{1}{c}{ Designation } & Gender & Years in Organization \\
\hline Chief Financial Officer (CFO) & Male & 20 \\
Director Human Resource (HR) & Female & 8 \\
General Manager (GM) Corporate Affairs & Female & 3 \\
General Manager (GM) Production & Male & 7 \\
Manager Quality Control & Male & 4 \\
Manager IT & Female & 6 \\
Manager Marketing & Male & 2 \\
\hline
\end{tabular}

